\title{
Modeling Leaf Area Estimation for Arabica Coffee (Coffea arabica L.) Grown at Different Altitudes of Mana District, Jimma Zone
}

\author{
Zerihun Misgana', Gerba Daba², Adugna Debela ${ }^{3}$ \\ ${ }^{1}$ College of Agriculture, Department of Plant Sciences, Oda Bultum University, Ciro PoBox 226, Ethiopia \\ ${ }^{2}$ Collage of Agriculture and Veterinary Medicine, Department of Horticulture and Plant Sciences, Jimma University, Jimma PoBox \\ 307, Ethiopia \\ ${ }^{3}$ Ethiopian Horticulture and Agriculture Investment Authority, Addis Ababa, Ethiopia \\ Email: zerishb23@gmail.com
}

How to cite this paper: Misgana, Z., Daba, G. and Debela, A. (2018) Modeling Leaf Area Estimation for Arabica Coffee (Coffea arabica L.) Grown at Different Altitudes of Mana District, Jimma Zone. American Journal of Plant Sciences, 9, 1292-1307.

https://doi.org/10.4236/ajps.2018.96095

Received: September 27, 2017

Accepted: May 27, 2018

Published: May 30, 2018

Copyright (c) 2018 by authors and Scientific Research Publishing Inc. This work is licensed under the Creative Commons Attribution International License (CC BY 4.0).

http://creativecommons.org/licenses/by/4.0/

\begin{abstract}
This study was aimed at establishing allometric models for estimating LA (Leaf Area) of eight Coffea arabica genotypes in Mana district of Jimma Zone Oromia Regional State, South Western Ethiopia $\left(7^{\circ} 46^{\prime} \mathrm{N}, 36^{\circ} 0^{\prime} \mathrm{E}\right)$. Many Methodologies and instruments have been devised to facilitate measurement of leaf area. However, these methods are destructive, laborious and expensive. For modeling leaf area, leaf width, leaf length and leaf area of 1200 leaves (50 leaves for each genotype) was measured for model calibration and the respective measurements on 960 leaves were used for model validation. Linear measurement was taken from leaves and branch diameters of eight genotypes of $C$. arabica, cultivated in field following a randomized complete blocks design at three altitudes (High, Medium and Low) were evaluated to identify best option for input in the models, and to validate the method to estimate the leaf area. Linear and non-linear models were tested for their accuracy to predict leaf area of the eight $C$. arabica genotypes. The use of linear model resulted in high accuracy for all of the eight C. arabica genotypes. No significant effect of growing altitude and genotype was obtained among the slopes of the models. Therefore, one single model was fitted to the combined data of all genotypes at all altitudes (LA $=0.6434 \mathrm{LW})$. Comparison between observed and predicted leaf area was made using this model in another independent dataset, conducted for model validation, exhibited a high degree of correlation $(r=0.98-0.99, \mathrm{P}<0.01)$. The over or under estimation of the leaf area using this model ranges between $0.02 \%$ to $1.7 \%$ and this model is adequate to estimate the leaf area for the eight $C$. arabica genotypes. Hence, this model can be proposed to be reliably used and with this developed model, researchers can estimate the leaf area of newly released eight genotypes of $C$. arabica at different altitudes accurately.
\end{abstract}




\section{Keywords}

Coffea arabica L., Modeling, Leaf Area Estimation

\section{Introduction}

Arabica coffee plays a significant role in Ethiopian economy, contributing over $35 \%$ of the total export value; $4 \%$ to $5 \%$ to National Gross Domestic Product and generating $20 \%$ of government revenue [1]. It also plays a central role as source of income for over one million coffee growing households, and over 15 million people derive their livelihood directly or indirectly from this crop along the value chain [1] [2].

In Ethiopia, the variability of coffee character is very wide for making use of the planting materials for different purposes. The presence of genetic diversity enables the country to select the planting materials for disease resistance, high yielding and of top quality coffee production in the country. This genetic diversity requires special care and proper utilization for sustainability of coffee production in the country in particular and to the world in general (http://www.ecea.org.et/altitude-and-climate).

It has been reported that leaves play an important role for plants to undertake gas exchange and carbon assimilation. Leaf area influences the growth and physiologies of the plants in many ways [3] [4] [5] [6]. It strongly affects light interception, physiology as well as productivity of the plant. It also affects photosynthesis, evapotranspiration, and response to fertilizer and irrigation [4] [5] [7] [8]. Therefore, the knowledge of leaf area is vital and employed as key trait for Eco physiological and agronomic studies [4] [9] [10]. For this reason, quantifying Leaf Area is fundamental for assessing plant primary productivity [4] and as a functional component of crop modeling [11].

Many methodologies and instruments have been devised to facilitate measurement of leaf area (copying on graph paper, photographing, use of a portable scanning planimeter, analysis of images using software [12] and these methods may or may not be destructive [13]). For methods such as copying on graph paper, photographing, or using a planimeter, cutting the leaf is necessary, to measure the leaf area and it is destructive [11]. However, the greatest limitation of such methodology is the impossibility of taking successive measurements through time on the same leaf. Additionally, the resulting defoliation may alter other experimental measurements [6] [10] [12] [14]. In certain cases, when the number of leaves to be assessed is high, quantification of LA is costly in time and resources [7]. Non-destructive methods, such as the use of a portable scanning planimeter, can be fast and precise [15] but are only feasible on small plants with few leaves [16]. Alternatively, analysis of images using software is also fast and precise [17] but may be limited by not being user-friendly.

An essential aspect of studies on plant growth and reproduction is the accu- 
rate and nondestructive estimation of key variables of interest such as leaf area, foliage or stem biomass, and total (stem + leaves) biomass, using the least amount of measurements. Such estimation implies the need for accurate and reliable predictive models [9]. These models are based on statistical relationships between a key variable of interest and one or several variables that are easy to measure [18]. The theoretical basis of these models is allometry which is defined as the measure and the study of growth or size of a part in relation to entire organism [19].

Allometric models have mainly been developed for their application for Coffea arabica. But as new processes of breeding and selections are performed, some morphological traits of the plants may be influenced, making it necessary to develop new methods. Leaf area has been developed by many authors and for different coffee genotypes such [7] coffee (Coffea arabica and Coffea canephora), [20] for genotypes of conilon coffee and [21] (Coffea arabica L.) of the Castillo variety.

However, this research did not consider the altitude differences of coffee genotypes to be incorporated in to the model for leaf area estimation and so far there has not been any research conducted for non-destructive leaf area estimation for Coffea arabica genotypes in Ethiopia at different altitude. In Ethiopia 37 improved (34 varieties and-3 hybrids) coffee varieties were released for different agro ecological areas of Ethiopia [22]. But there has not been any research conducted to develop allometric nondestructive branch growth and leaf area estimation for these genotypes.

Therefore, developing models that allow prediction of leaf area and branch biomass of the released genotypes of Coffee Arabica in accurate and simple ways are very important, as they are less economically costly and enable measurements on the same leaf over time, making it possible to describe accurate patterns of growth. To this effect, the current research was initiated to develop simple and reliable model for nondestructive leaf area estimation of eight Coffea arabica L. genotypes grown at three different altitudes of Mana District, Jimma Zone.

\section{Materials and Methods}

\subsection{Description of Experimental Sites}

The experiment was conducted at three different locations Buture, Gembe and Degalu all in Mana district of Jimma zone, Oromia Regional state, South Western Ethiopia $\left(7^{\circ} 46^{\prime} \mathrm{N}, 36^{\circ} 0^{\prime} \mathrm{E}\right)$. This area receives adequate amount of rainfall with annual average rainfall of $1595 \mathrm{~mm}$ per annum. In this area, the driest season lasts between December and January. The maximum and minimum air temperature is $25.9^{\circ} \mathrm{C}$ and $11.2^{\circ} \mathrm{C}$, respectively with the coldest month being December [23]. The experimental areas have the potential for coffee production and each location has different altitudes. The description of the locations in terms of altitude, latitude and longitude are as shown in (Table 1). 
Table 1. Description of the three locations that were used in the study.

\begin{tabular}{cccccc}
\hline No. & $\begin{array}{c}\text { Location } \\
\text { name }\end{array}$ & Altitude (m.a.l) & Longitude & Latitude & $\begin{array}{c}\text { Distance from } \\
\text { Jimma town in }(\mathrm{km})\end{array}$ \\
\hline 1 & Degelu & 1450 & $37^{\circ} 02^{\prime} 43^{\prime \prime} \mathrm{E}$ & $08^{\circ} 67^{\prime} 96^{\prime \prime N}$ & 35 \\
2 & Gembe & 1610 & $37^{\circ} 07^{\prime} 44^{\prime \prime} \mathrm{E}$ & $08^{\circ} 67^{\prime} 10^{\prime \prime N}$ & 32 \\
3 & Buture & 2063 & $37^{\circ} 02^{\prime} 50^{\prime \prime} \mathrm{E}$ & $08^{\circ} 56^{\prime} 96^{\prime \prime} \mathrm{N}$ & 19 \\
\hline
\end{tabular}

\subsection{Experimental Materials}

Eight coffee Arabica genotypes have already been established since June 01, 2012 at three different locations and during this experiment, these eight genotypes (74-1, 75-227, 74-54, 74-112, 74-140, 74-148, 74-158 and 74-165) were used in May 2016. Twenty five plants (in five rows having five plants in each row) of each genotype were planted in each plot with plot size measuring $10 \mathrm{~m} \times 10 \mathrm{~m}$ in $2 \mathrm{~m} \times 2 \mathrm{~m}$ spacing giving a density of 2500 plants per hectare and planting depth of $0.6 \mathrm{~m} \times 0.6 \mathrm{~m}$. Crop management practices were similar for all locations.

\subsection{Experimental Design and Layout of the Experiment}

The treatments were arranged in a randomized complete block design (RCBD) with three replications as indicated in the layout below. The treatments consist of eight Coffea arabica genotypes with three altitudes.

\begin{tabular}{ccccccccc}
\hline BLOCK-I & $74-112$ & $74-165$ & $75-227$ & $74-1$ & $74-140$ & $74-158$ & $74-148$ & $74-54$ \\
Block-II & $74-148$ & $74-1$ & $74-158$ & $74-112$ & $74-54$ & $75-227$ & $74-140$ & $74-165$ \\
Block-III & $74-158$ & $74-140$ & $74-54$ & $74-148$ & $74-165$ & $74-112$ & $75-227$ & $74-1$ \\
\hline
\end{tabular}

\subsection{Sampling Method and Data Collection}

For model development, five individual plants were randomly taken for each coffee genotype at each location. For each individual plant, five twigs were sampled using cutting scissors. Then after, ten leaves per plants for each genotype at each location were collected using method of [5]. Fifty leaves were collected for each genotype per location for model development (five plants $\times$ ten leaves).

For model validation, four individual plants were randomly taken for each coffee genotype at each location. For each individual plant five twigs were sampled using cutting scissors; then after 10 leaves were cut per plant for each genotype. Forty leaves were collected for each genotype per location for model construction (four plants $\times$ ten leaves).

Totally, 1200 leaves (Fifty Leafs $\times$ eight Genotypes $\times$ three Locations) were used for model development and 960 leaves (Forty Leafs $\times$ eight Genotypes $\times$ three Locations) were used for model validation during leaf area measurements.

\subsection{Measuring of Leaf Dimensions}

During measurement for model development and model validation, maximum leaf length from lamina tip to the point of petiole insertion along the midrib was 
measured using ruler with care. Leaf widths in centimeter at the widest point perpendicular to the midrib were measured for all leaves of the Coffea arabica genotypes using ruler [13]. We had to use leaf area meter for measuring leaf area but the leaf area meter currently available in JUCAM is not functional and even we did not find it elsewhere in the country for measuring leaf area. For this reason we used square meter to measure leaf area. Area of each leaf were measured by drawing each leaf on square paper and the squares in each leaf was counted and the number was multiplied with the area of the square to get the leaf area $\left(\mathrm{cm}^{2}\right)$.

\subsection{Model Development and Validation}

Four linear regression models, one power model and one logarithmic model were employed for model building for leaf area estimation. Leaf length $(\mathrm{L})$ and leaf width $(\mathrm{W})$ dimensions and LA were those variables consider in building models. The following models $(\mathrm{Y}=\mathrm{aL}+\mathrm{b}, \mathrm{Y}=\mathrm{aW}+\mathrm{b}, \mathrm{Y}=\mathrm{aLW}+\mathrm{b}, \mathrm{Y}=\mathrm{aL}+$ $\mathrm{bW}+\mathrm{c}, \mathrm{Y}=\mathrm{ax}^{\mathrm{b}}, \mathrm{Y}=\mathrm{aLnx}+\mathrm{b}$ ) linear, power and logarithmic models were used, respectively. Where: $\mathrm{Y}=$ Leaf area $\left(\mathrm{cm}^{2}\right), \mathrm{L}=$ Length $(\mathrm{cm}), \mathrm{W}=$ Width $(\mathrm{cm}), \mathrm{a}=$ Slope and $\mathrm{b}=$ intercept $\left(\mathrm{cm}^{2}\right)$. All models were run for each genotype at three locations and the best model was selected based on Statistical criteria for model selection. Coefficient of determination $\left(R^{2}\right)$, standard error of estimates (SE) RMSE and CV were the Statistical criteria used for model selection method used by [24]. This criterion helps in evaluating the occurrence of bias and model precision and accuracy. The final model to estimate leaf area was selected based on the Statistical criteria for model selection. They are the combination of the highest $R^{2}$ and the lowest root mean square error (RMSE) and root mean square error (RMSE), lowest bias of linear regressed line between observed versus predicted values from the 1:1 line and lowest coefficient of variance $(\mathrm{CV})$ were determined using the following formulas.

$$
\begin{aligned}
& \text { RMSE }=\sqrt{\sum_{i=1}^{n}\left(Y_{i}-Y o\right)^{2} / n} \\
& \text { Bias }=\sum \frac{(Y i-Y o)}{n}
\end{aligned}
$$

where " $n$ " is the number of observations, "Yi" and " $Y o$ " are the estimated and measured leaf area values of $I^{\text {th }}$ observation. The RMSE tests the accuracy of the model which is defined as the extent to which predicted values approach a corresponding set of measured values. Beside this, coefficient of variation (CV) was also used to validate the models. CV was calculated from the following equation:

$$
\begin{aligned}
\mathrm{CV}(\%) & =\mathrm{RMSE} \times 100 / x \\
\mathrm{MSE} & =\mathrm{RMSE}^{1 / 2}
\end{aligned}
$$

where " $x$ " is the mean observed values.

Equality of a set of regression models between each location for each geno- 
type, were tested using ANCOVA (Analysis of Covariance). When no significant differences were found, data were pooled to construct a single regression. Since applying two dimensional measurements would introduce potential problems of collinearity, which would lead to poor precision in the estimates of corresponding regression coefficients, the variance inflation factor (VIF, Marquardt 1970) and the tolerance value (T, Gill 1986) cited in [25] were calculated to detect collinearity in two-dimensional models as follows:

$$
\begin{gathered}
\mathrm{VIF}=1 /\left(1-r^{2}\right) \\
\mathrm{T}=1 / \mathrm{VIF}
\end{gathered}
$$

where: $r$ is the correlation coefficient.

If the VIF value is higher than 10 or $\mathrm{T}$ value (tolerance value) smaller than 0.10 , consequently one of them will be excluded from the model because the impact of collinearity on the estimates of the parameters cannot be neglected [2] [26].

In order to validate the selected model, estimated LA was predicted using the developed model and the slopes of the regressions between observed LA and estimated LA were tested for their significant difference from the respective of the 1:1 correspondence line methods used by (Dent and Blackie, 1979 cited in [27].

\subsection{Method of Data Analysis}

All the collected data were first tested for homogeneity using Tukey's before being subjected to regression analysis and were analyzed with regression using SAS 9.3 Software. The differences in slopes and intercepts between models were tested using ANCOVA for testing whether two slopes and intercepts computed from two groups are significantly different.

\section{Results and Discussion}

\subsection{Models Developed for Leaf Area Estimation}

Different prediction equations were obtained for estimating the LA of coffee Arabica involving two independent variables leaf length (L), and leaf width (W), and their product $(\mathrm{L} \times \mathrm{W})$ were tested for estimating leaf area by using different equations. Among all tested linear regression models $(\mathrm{Y}=\mathrm{aL}+\mathrm{b}, \mathrm{Y}=\mathrm{aW}+\mathrm{b}, \mathrm{Y}$ $=\mathrm{aLW}+\mathrm{b}, \mathrm{Y}=\mathrm{aL}+\mathrm{bW}+\mathrm{c}$ ) equations using leaf length $(\mathrm{L})$, and maximum leaf width $(\mathrm{W}), \mathrm{Y}=\mathrm{aLW}+\mathrm{b}$ had strong relationships with LA and resulted in high coefficients of determination $\left(R^{2}\right)$ lowest standard error for all genotypes at all. For few of the genotypes, (74-140, 74-148 and 74-54 at Buture, 74-158 and 74-54 at Degalu and 74-148 at Gembe) $\mathrm{Y}=\mathrm{aL}+\mathrm{bW}+\mathrm{c}$ had strong relationships with Leaf Area. However, this model was neglected because there was a problem of co-linearity between L and W (VIF value was higher than 10 or/and tolerance value ( $\mathrm{T}$ value) smaller than 0.10 ). Therefore, for all locations and genotypes $\mathrm{Y}=$ $\mathrm{aLW}+\mathrm{b}$ had the most predictive power than the rest models tested to estimate leaf area of Coffea arabica L. genotypes. 
The models, power $(\mathrm{Y}=\mathrm{ax})$, logarithmic $(\mathrm{Y}=\mathrm{aLnx}+\mathrm{b})$ and linear $(\mathrm{Y}=\mathrm{ax}+$ b) models were tested. Among the three tested models (linear $Y=a x+b$ ) had the highest coefficients of determination $R^{2}$ and therefore, model was selected for all genotypes at all locations (Tables 2-4). However, a better fit was achieved using $\mathrm{L}^{*} \mathrm{~W}$ without intercept $(Y=a \mathrm{LW})$ than using $\mathrm{L} * \mathrm{~W}$ with intercept $(Y=a$ $\mathrm{LW}+b$ ) for all of the eight Coffea arabica genotypes tested (Tables 2-4).

Table 2. Form of model tested and their coefficient of determination $\left(R^{2}\right)$, to estimate Leaf Area of eight coffee Arabica genotypes at different altitude using the product of Length and Width at Buture, where " $y$ " is the measured leaf area $\left(\mathrm{cm}^{2}\right)$, "a" is the slope, " $\mathrm{b}$ " is the intercept, and " $\mathrm{x}$ " is the independent variable.

\begin{tabular}{|c|c|c|c|c|c|}
\hline Genotype & Model & a & b & $\mathbf{R}^{2}$ & Equation \\
\hline \multirow{4}{*}{$74-112$} & $y=a x+b$ & 0.6742 & -1.2666 & 0.9813 & $\mathrm{Y}=0.6742(\mathrm{x})-1.2666$ \\
\hline & $y=a x$ & 0.6506 & - & 0.9980 & $\mathrm{Y}=0.6506(\mathrm{x})$ \\
\hline & $y=a \operatorname{Ln} x+b$ & 32.349 & -92.732 & 0.9318 & $\mathrm{Y}=32.349 \ln (\mathrm{x})-92.732$ \\
\hline & $y=a x^{b}$ & 0.619 & 1.0112 & 0.9791 & $\mathrm{Y}=0.619(\mathrm{x})^{1.0112}$ \\
\hline \multirow{4}{*}{$74-165$} & $y=a x+b$ & 0.6276 & 71.0097 & 0.9848 & $\mathrm{Y}=0.6276(\mathrm{x})+71.0097$ \\
\hline & $y=a x$ & 0.6477 & - & 0.9987 & $\mathrm{Y}=0.6477(\mathrm{x})$ \\
\hline & $y=a \operatorname{Ln} x+b$ & 29.894 & -83.318 & 0.9481 & $\mathrm{Y}=29.894 \ln (\mathrm{x})-83.318$ \\
\hline & $\mathrm{y}=\mathrm{ax}$ & 0.7883 & 0.9479 & 0.9819 & $\mathrm{Y}=0.7883(\mathrm{x})^{0.9479}$ \\
\hline \multirow{4}{*}{$75-225$} & $y=a x+b$ & 0.6577 & -0.4412 & 0.9730 & $\mathrm{Y}=0.6577(\mathrm{x})-0.4412$ \\
\hline & $y=a x$ & 0.6471 & & 0.9992 & $\mathrm{Y}=0.6471(\mathrm{x})$ \\
\hline & $y=a \operatorname{Ln} x+b$ & 27.018 & -73.436 & 0.9543 & $\mathrm{Y}=27.018 \ln (\mathrm{x})-73.436$ \\
\hline & $y=a x^{b}$ & 0.6333 & 1.0055 & 0.969 & $\mathrm{Y}=0.6333(\mathrm{x})^{1.0055}$ \\
\hline \multirow{4}{*}{$74-1$} & $y=a x+b$ & 0.6117 & 0.9588 & 0.9775 & $\mathrm{Y}=0.6117(\mathrm{x})+0.9588$ \\
\hline & $y=a x$ & 0.6347 & - & 0.9991 & $\mathrm{Y}=0.6347(\mathrm{x})$ \\
\hline & $y=a \operatorname{Ln} x+b$ & 23.77 & -61.769 & 0.9602 & $\mathrm{Y}=23.77 \ln (\mathrm{x})-61.769$ \\
\hline & $y=a x^{b}$ & 0.7535 & 0.954 & 0.9765 & $\mathrm{Y}=0.7535(\mathrm{x})^{0.954}$ \\
\hline \multirow{4}{*}{$74-140$} & $y=a x+b$ & 0.6309 & 0.6095 & 0.9854 & $\mathrm{Y}=0.6309(\mathrm{x})+0.6095$ \\
\hline & $y=a x$ & 0.6450 & - & 0.9989 & $\mathrm{Y}=0.6450(\mathrm{x})$ \\
\hline & $y=a \operatorname{Ln} x+b$ & 25.309 & -66.765 & 0.972 & $\mathrm{Y}=25.309 \ln (\mathrm{x})-66.765$ \\
\hline & $y=a x^{b}$ & 0.6682 & 0.9908 & 0.9804 & $\mathrm{Y}=0.6682(\mathrm{x})^{0.9908}$ \\
\hline \multirow{4}{*}{$74-158$} & $y=a x+b$ & 0.6464 & 0.5068 & 0.9682 & $\mathrm{Y}=0.6464(\mathrm{x})+0.5068$ \\
\hline & $y=a x$ & 0.6563 & - & 0.9986 & $\mathrm{Y}=0.6563(\mathrm{x})$ \\
\hline & $y=a \operatorname{Ln} x+b$ & 30.633 & -86351 & 0.9465 & $\mathrm{Y}=30.633 \ln (\mathrm{x})-86351$ \\
\hline & $y=a x^{b}$ & 0.7322 & 0.972 & 0.9664 & $\mathrm{Y}=0.7322(\mathrm{x})^{0.972}$ \\
\hline \multirow{4}{*}{$74-148$} & $y=a x+b$ & 0.6065 & 71.293 & 0.9239 & $\mathrm{Y}=0.6065(\mathrm{x})+71.293$ \\
\hline & $y=a x$ & 0.6351 & - & 0.9978 & $\mathrm{Y}=0.6351(\mathrm{x})$ \\
\hline & $y=a \operatorname{Ln} x+b$ & 26.651 & -72.52 & 0.9116 & $\mathrm{Y}=26.651 \ln (\mathrm{x})-72.52$ \\
\hline & $y=a x^{b}$ & 0.7995 & 0.9564 & 0.9216 & $\mathrm{Y}=0.7995(\mathrm{x})^{0.9564}$ \\
\hline \multirow{4}{*}{$74-54$} & $y=a x+b$ & 0.6156 & 0.7748 & 0.9768 & $\mathrm{Y}=0.6156(\mathrm{x})+0.7748$ \\
\hline & $y=a x$ & 0.6357 & - & 0.9990 & $\mathrm{Y}=0.6357(\mathrm{x})$ \\
\hline & $y=a \operatorname{Ln} x+b$ & 22.17 & -56.026 & 0.9532 & $\mathrm{Y}=22.17 \ln (\mathrm{x})-56.026$ \\
\hline & $y=a x^{b}$ & 0.7456 & 0.9563 & 0.9758 & $\mathrm{Y}=0.7456(\mathrm{x})^{0.9563}$ \\
\hline
\end{tabular}


Table 3. Form of model tested and their coefficient of determination $\left(\mathrm{R}^{2}\right)$, to estimate Leaf Area of eight coffee Arabica genotypes at different altitude using the product of Length and Width at Degalu, where " $y$ " is the measured leaf area $\left(\mathrm{cm}^{2}\right)$, "a" is the slope, " $b$ " is the intercept, and " $x$ " is the independent variable.

\begin{tabular}{|c|c|c|c|c|c|}
\hline Genotype & Model & a & b & $\mathbf{R}^{2}$ & Equation \\
\hline \multirow{4}{*}{$74-112$} & $y=a x+b$ & 0.6503 & -0.8269 & 0.9785 & $\mathrm{Y}=0.6503(\mathrm{x})-0.8269$ \\
\hline & $y=a x$ & 0.6380 & - & 0.9987 & $\mathrm{Y}=0.6380(\mathrm{x})$ \\
\hline & $y=a \operatorname{Ln} x+b$ & 39.576 & -122.6 & 0.9544 & $\mathrm{Y}=39.576 \ln (\mathrm{x})-122.6$ \\
\hline & $y=a x^{b}$ & 0.5962 & 1.0157 & 0.9779 & $\mathrm{Y}=0.5962(\mathrm{x})^{1.0157}$ \\
\hline \multirow{4}{*}{$74-165$} & $y=a x+b$ & 0.5942 & 1.3995 & 0.9806 & $\mathrm{Y}=0.5942(\mathrm{x})+1.3995$ \\
\hline & $y=a x$ & 0.6266 & - & 0.9991 & $\mathrm{Y}=0.6266(\mathrm{x})$ \\
\hline & $y=a \operatorname{Ln} x+b$ & 43.398 & -64.257 & 0.9665 & $\mathrm{Y}=43.398 \ln (\mathrm{x})-64.257$ \\
\hline & $y=a x^{b}$ & 0.7621 & 0.9482 & 0.9773 & $\mathrm{Y}=0.7621(\mathrm{x})^{0.9482}$ \\
\hline \multirow{4}{*}{$75-225$} & $y=a x+b$ & 0.6607 & -0.4945 & 0.9903 & $\mathrm{Y}=0.6607(\mathrm{x})-0.4945$ \\
\hline & $y=a x$ & 0.6514 & - & 0.9987 & $\mathrm{Y}=0.6514(\mathrm{x})$ \\
\hline & $y=a \operatorname{Ln} x+b$ & 31.615 & -89.182 & 0.9165 & $\mathrm{Y}=31.615 \ln (\mathrm{x})-89.182$ \\
\hline & $y=a x^{b}$ & 0.6391 & 1.004 & 0.9857 & $\mathrm{Y}=0.6391(\mathrm{x})^{1.004}$ \\
\hline \multirow{4}{*}{$74-1$} & $y=a x+b$ & 0.666 & -0.5462 & 0.9753 & $\mathrm{Y}=0.666(\mathrm{x})-0.5462$ \\
\hline & $y=a x$ & 0.6528 & - & 0.9975 & $\mathrm{Y}=0.6528(\mathrm{x})$ \\
\hline & $y=a \operatorname{Ln} x+b$ & 24.901 & -64.635 & 0.9235 & $\mathrm{Y}=24.901 \ln (\mathrm{x})-64.635$ \\
\hline & $y=a x^{b}$ & 0.6652 & 0.9933 & 0.9508 & $\mathrm{Y}=0.6652(\mathrm{x})^{0.9933}$ \\
\hline \multirow{4}{*}{$74-140$} & $y=a x+b$ & 0.6280 & 1.0732 & 0.9891 & $\mathrm{Y}=0.628(\mathrm{x})+1.0732$ \\
\hline & $y=a x$ & 0.6503 & - & 0.9982 & $\mathrm{Y}=0.6503(\mathrm{x})$ \\
\hline & $y=a \operatorname{Ln} x+b$ & 26.879 & -70.756 & 0.9574 & $\mathrm{Y}=26.879 \ln (\mathrm{x})-70.756$ \\
\hline & $y=a x^{b}$ & 0.7568 & 0.9613 & 0.9837 & $\mathrm{Y}=0.7568(\mathrm{x})^{0.9613}$ \\
\hline \multirow{4}{*}{$74-158$} & $y=a x+b$ & 0.6272 & 0.7945 & 0.9898 & $\mathrm{Y}=0.62729(\mathrm{x})+0.7945$ \\
\hline & $y=a x$ & 0.6442 & - & 0.9988 & $\mathrm{Y}=0.6442(\mathrm{x})$ \\
\hline & $y=a \operatorname{Ln} x+b$ & 25.22 & -66.153 & 0.9628 & $\mathrm{Y}=25.22 \ln (\mathrm{x})-66.153$ \\
\hline & $y=a x^{b}$ & 0.6886 & 0.9829 & 0.9827 & $\mathrm{Y}=0.6886(\mathrm{x})^{0.9829}$ \\
\hline \multirow{4}{*}{$74-148$} & $y=a x+b$ & 0.6323 & 0.1912 & 0.9865 & $\mathrm{Y}=0.6323(\mathrm{x})+0.1912$ \\
\hline & $y=a x$ & 0.6365 & - & 0.9988 & $\mathrm{Y}=0.6365(\mathrm{x})$ \\
\hline & $y=a \operatorname{Ln} x+b$ & 28.342 & -77.998 & 0.9712 & $\mathrm{Y}=28.342 \ln (\mathrm{x})-77.998$ \\
\hline & $y=a x^{b}$ & 0.6181 & 1.0079 & 0.9810 & $\mathrm{Y}=0.6181(\mathrm{x})^{1.0079}$ \\
\hline \multirow{4}{*}{$74-54$} & $y=a x+b$ & 0.6312 & 0.7028 & 0.9841 & $\mathrm{Y}=0.6312(\mathrm{x})+0.7028$ \\
\hline & $y=a x$ & 0.6439 & - & 0.9978 & $\mathrm{Y}=0.6439(\mathrm{x})$ \\
\hline & $y=a \operatorname{Ln} x+b$ & 29.692 & -82.343 & 0.9448 & $\mathrm{Y}=29.692 \ln (\mathrm{x})-82.343$ \\
\hline & $y=a x^{b}$ & 0.67 & 0.9903 & 0.9805 & $\mathrm{Y}=0.67(\mathrm{x})^{0.9903}$ \\
\hline
\end{tabular}


Table 4. Form of model tested and their coefficient of determination $\left(\mathrm{R}^{2}\right)$, to estimate Leaf Area of eight coffee Arabica genotypes at different altitude using the product of Length and Width at Gembe, where " $y$ " is the measured leaf area $\left(\mathrm{cm}^{2}\right)$, "a" is the slope, " $b$ " is the intercept, and " $\mathrm{x}$ " is the independent variable.

\begin{tabular}{|c|c|c|c|c|c|}
\hline Genotype & Model & a & b & $\mathbf{R}^{2}$ & Equation \\
\hline \multirow{4}{*}{$74-112$} & $y=a x+b$ & 0.6372 & -0.3045 & 0.9766 & $\mathrm{Y}=0.6372(\mathrm{x})-0.3045$ \\
\hline & $y=a x$ & 0.6339 & - & 0.9985 & $\mathrm{Y}=0.6339(\mathrm{x})$ \\
\hline & $y=a \operatorname{Ln} x+b$ & 41.096 & -129.31 & 0.9321 & $\mathrm{Y}=41.096 \ln (\mathrm{x})-129.31$ \\
\hline & $y=a x^{b}$ & 0.6876 & 0.9803 & 0.9704 & $\mathrm{Y}=0.6876(\mathrm{x})^{0.9803}$ \\
\hline \multirow{4}{*}{$74-165$} & $y=a x+b$ & 0.636 & -0.0565 & 0.9886 & $\mathrm{Y}=0.636(\mathrm{x})-0.0565$ \\
\hline & $y=a x$ & 0.6348 & - & 0.9993 & $\mathrm{Y}=0.6348(\mathrm{x})$ \\
\hline & $y=a \operatorname{Ln} x+b$ & 26.641 & -72.013 & 0.9668 & $\mathrm{Y}=26.641 \ln (\mathrm{x})-72.013$ \\
\hline & $y=a x^{b}$ & 0.6351 & 0.9997 & 0.9881 & $\mathrm{Y}=0.6351(\mathrm{x})^{0.9997}$ \\
\hline \multirow{4}{*}{$75-225$} & $y=a x+b$ & 0.6577 & -0.5511 & 0.9848 & $\mathrm{Y}=0.6577(\mathrm{x})-0.5511$ \\
\hline & $y=a x$ & 0.6499 & - & 0.9981 & $\mathrm{Y}=0.6499(\mathrm{x})$ \\
\hline & $y=a \operatorname{Ln} x+b$ & 42.081 & -130.36 & 0.9540 & $\mathrm{Y}=42.081 \ln (\mathrm{x})-130.36$ \\
\hline & $y=a x^{b}$ & 0.5961 & 0.02 & 0.9840 & $\mathrm{Y}=0.5961(\mathrm{x})^{0.02}$ \\
\hline \multirow{4}{*}{$74-1$} & $y=a x+b$ & 0.6516 & -0.0844 & 0.9784 & $\mathrm{Y}=0.6516(\mathrm{x})-0.0844$ \\
\hline & $y=a x$ & 0.6499 & - & 0.9982 & $\mathrm{Y}=0.6499(\mathrm{x})$ \\
\hline & $y=a \operatorname{Ln} x+b$ & 30.745 & -86.382 & 0.9522 & $\mathrm{Y}=30.745 \ln (\mathrm{x})-86.382$ \\
\hline & $y=a x^{b}$ & 0.6365 & 1.005 & 0.9774 & $\mathrm{Y}=0.6365(\mathrm{x})^{1.005}$ \\
\hline \multirow{4}{*}{$74-140$} & $y=a x+b$ & 0.6193 & 1.7383 & 0.9844 & $\mathrm{Y}=0.6193(\mathrm{x})+1.7383$ \\
\hline & $y=a x$ & 0.6539 & - & 0.9982 & $\mathrm{Y}=0.6539(\mathrm{x})$ \\
\hline & $y=a \operatorname{Ln} x+b$ & 28.413 & -76.989 & 0.9535 & $\mathrm{Y}=28.413 \ln (\mathrm{x})-76.989$ \\
\hline & $y=a x^{b}$ & 0.7518 & 0.9654 & 0.9838 & $\mathrm{Y}=0.7518(\mathrm{x})^{0.9654}$ \\
\hline \multirow{4}{*}{$74-158$} & $y=a x+b$ & 0.6104 & 1.3566 & 0.9821 & $\mathrm{Y}=0.6104(\mathrm{x})+1.3566$ \\
\hline & $y=a x$ & 0.6388 & - & 0.9979 & $\mathrm{Y}=0.6388(\mathrm{x})$ \\
\hline & $y=a \operatorname{Ln} x+b$ & 24.776 & -64.464 & 0.9429 & $\mathrm{Y}=24.776 \ln (\mathrm{x})-64.464$ \\
\hline & $y=a x^{b}$ & 0.791 & 0.9448 & 0.9754 & $\mathrm{Y}=0.791(\mathrm{x})^{0.9448}$ \\
\hline \multirow{4}{*}{$74-148$} & $y=a x+b$ & 0.6127 & 2.1606 & 0.9722 & $\mathrm{Y}=35.269(\mathrm{x})-103.89$ \\
\hline & $y=a x$ & 0.6447 & - & 0.9980 & $\mathrm{Y}=0.6447(\mathrm{x})$ \\
\hline & $y=a \operatorname{Ln} x+b$ & 35.269 & -103.89 & 0.9531 & $\mathrm{Y}=35.269 \ln (\mathrm{x})-103.89$ \\
\hline & $y=a x^{b}$ & 0.7916 & 0.9515 & 0.960 & $\mathrm{Y}=0.7916(\mathrm{x})^{0.9515}$ \\
\hline \multirow{4}{*}{$74-54$} & $y=a x+b$ & 0.6361 & 0.4031 & 0.9881 & $\mathrm{Y}=0.6361(\mathrm{x})+0.4031$ \\
\hline & $y=a x$ & 0.6433 & - & 0.9985 & $\mathrm{Y}=0.6433(\mathrm{x})$ \\
\hline & $y=a \operatorname{Ln} x+b$ & 31.839 & -91.613 & 0.9517 & $\mathrm{Y}=31.839 \operatorname{Ln}(\mathrm{x})-91.613$ \\
\hline & $y=a x^{b}$ & 0.6255 & 1.0069 & 0.9609 & $\mathrm{Y}=0.6255(\mathrm{x})^{1.0069}$ \\
\hline
\end{tabular}


Slopes of the models developed for each genotype at each location showed no significant difference $(\mathrm{P}>0.05)$ among the genotypes (Table 5). Then the data were pooled and a single regression model was developed for each genotype at all locations (Table 6). Slopes of the models developed for each genotype at all location also showed no significant difference $(\mathrm{P}>0.05)$ among the three locations.

Table 5. Slopes of the model $(Y=a L W)$ estimating leaf area using leaf length $(\mathrm{L})$ and width (W) of eight Arabica coffee genotypes at three locations, (L) and (W) in cm and Y in $\mathrm{cm}^{2}$. Differences in slopes of the models between location and genotypes were tested using ANCOVA.

\begin{tabular}{|c|c|c|c|c|c|c|c|c|}
\hline \multirow{4}{*}{ Genotypes } & \multirow{4}{*}{ Location } & \multirow{3}{*}{\multicolumn{2}{|c|}{$\begin{array}{c}\text { Selected Model } \\
\text { For Each location } \\
\text { Model } \\
\mathrm{Y}=\mathrm{aLW}\end{array}$}} & \multicolumn{5}{|c|}{$\begin{array}{l}\text { Common Model for each } \\
\text { genotype at all location }\end{array}$} \\
\hline & & & & \multirow{2}{*}{\multicolumn{5}{|c|}{ Regression coefficients }} \\
\hline & & & & & & & & \\
\hline & & Slope & $\mathbf{R}^{2}$ & Slope & RMSE & MSE & $\mathrm{CV}$ & $\mathbf{R}^{2}$ \\
\hline \multirow{3}{*}{$74-112$} & Buture & $0.6506^{\mathrm{a}}$ & 0.9980 & & & & & \\
\hline & Degalu & $0.6380^{\mathrm{a}}$ & 0.9987 & $0.6395^{\mathrm{a}}$ & 1.64 & 2.70 & 4.32 & 0.9983 \\
\hline & Gembe & $0.63308^{\mathrm{a}}$ & 0.9985 & & & & & \\
\hline \multirow{3}{*}{$74-165$} & Buture & $0.6471^{\mathrm{a}}$ & 0.9987 & & & & & \\
\hline & Degalu & $0.6266^{\mathrm{a}}$ & 0.9991 & $0.6380^{\mathrm{a}}$ & 1.01 & 1.038 & 3.65 & 0.9995 \\
\hline & Gembe & $0.6409^{\mathrm{a}}$ & 0.9993 & & & & & \\
\hline \multirow{3}{*}{$75-225$} & Buture & $0.6471^{\mathrm{a}}$ & 0.9992 & & & & & \\
\hline & Degalu & $0.65136^{\mathrm{a}}$ & 0.9987 & $0.6453^{\mathrm{a}}$ & 1.347 & 1.815 & 4.15 & 0.9995 \\
\hline & Gembe & $0.6409^{\mathrm{a}}$ & 0.9982 & & & & & \\
\hline \multirow{3}{*}{$74-1$} & Buture & $0.6347^{\mathrm{a}}$ & 0.9991 & & & & & \\
\hline & Degalu & $0.6528^{\mathrm{a}}$ & 0.9975 & $0.6456^{\mathrm{a}}$ & 1.221 & 1.492 & 4.60 & 0.9993 \\
\hline & Gembe & $0.6499^{\mathrm{a}}$ & 0.9981 & & & & & \\
\hline \multirow{3}{*}{$74-140$} & Buture & $0.6429^{\mathrm{a}}$ & 0.9989 & & & & & \\
\hline & Degalu & $0.6536^{\mathrm{a}}$ & 0.9982 & $0.6527^{\mathrm{a}}$ & 1.182 & 1.397 & 4.30 & 0.9992 \\
\hline & Gembe & $0.6592^{\mathrm{a}}$ & 0.9982 & & & & & \\
\hline \multirow{3}{*}{$74-158$} & Buture & $0.6563^{\mathrm{a}}$ & 0.9986 & & & & & \\
\hline & Degalu & $0.6442^{\mathrm{a}}$ & 0.9988 & $0.6468^{\mathrm{a}}$ & 1.246 & 1.554 & 4.22 & 0.9993 \\
\hline & Gembe & $0.6388^{a}$ & 0.9979 & & & & & \\
\hline \multirow{3}{*}{$74-148$} & Buture & $0.6351^{\mathrm{a}}$ & 0.9978 & & & & & \\
\hline & Degalu & $0.6365^{\mathrm{a}}$ & 0.9988 & $0.6389^{\mathrm{a}}$ & 1.458 & 2.128 & 4.60 & 0.9993 \\
\hline & Gembe & $0.6447^{\mathrm{a}}$ & 0.9980 & & & & & \\
\hline \multirow{3}{*}{$74-54$} & Buture & $0.6357^{\mathrm{a}}$ & 0.9990 & & & & & \\
\hline & Degalu & $0.6474^{\mathrm{a}}$ & 0.9978 & $0.6410^{\mathrm{a}}$ & 1.342 & 1.803 & 4.38 & 0.9994 \\
\hline & Gembe & $0.6433^{\mathrm{a}}$ & 0.9985 & & & & & \\
\hline
\end{tabular}

Values followed by different letters within a column show significant differences at $(\mathrm{p}<0.05)$. 
Table 6. Common Model for all genotypes at all location Y-Leaf area, Coefficient of determination $\left(\mathrm{R}^{2}\right)$, Standard Error (SE) and Root mean square Error (RMSE).

\begin{tabular}{cccccc}
\hline Model & \multicolumn{3}{c}{ Regression coefficient } & $\mathbf{R}^{2}$ & Equation \\
\hline $\mathrm{Y}=\mathrm{aLW}$ & Slope & $\mathrm{SE}$ & $\mathrm{RMSE}$ & \multirow{2}{*}{0.9993} & $\mathrm{Y}=0.6434 \mathrm{LW}$ \\
& $\mathbf{0 . 6 4 3 4}$ & 0.0008 & 1.2385 & & \\
\hline
\end{tabular}

All the leaf data from the eight genotypes at the three locations were pooled and a single regression model was developed for all genotypes (Table 6). Single regression model which was fitted to the combined data of all genotypes (LA = $0.6434 \mathrm{LW}$ ) had the highest coefficient of determination $\left(\mathrm{R}^{2}\right)$ and high precision (small SE) and Root mean square Error (RMSE) (Table 6). We found that the linear regression model $(\mathrm{LA}=0.6434 \mathrm{LW}$ ) best predicted the leaf area in respective of locations and genotypes of the eight Coffea arabica genotypes (Table 6). This finding was in agreement with other finds that developed a linear model for leaf area estimation in perennial crops [28].

\subsection{Model Validation}

The relationship between measured LA and predicted LA using the general equation (LA $=0.6434 \mathrm{LW}$ ) validated and had a good fit (Figure 1) for all the eight Coffea arabica genotypes. No significant difference $(\mathrm{P}>0.01)$ was obtained between the slopes of the regressions between Measured Leaf Area (MLA) and Estimated Leaf Area (ELA) from the 1:1 relationship (Figure 1). The leaf area estimated by the model was strongly correlated $(\mathrm{r}=0.99, \mathrm{P}<0.01, \mathrm{r}=0.98, \mathrm{P}<$ $0.01, \mathrm{r}=0.99, \mathrm{P}<0.01, \mathrm{r}=0.98, \mathrm{P}<0.01, \mathrm{r}=0.99, \mathrm{P}<0.01, \mathrm{r}=0.99, \mathrm{P}<0.01, \mathrm{r}=$ $0.98, \mathrm{P}<0.01, \mathrm{r}=0.98, \mathrm{P}<0.01$ ) with the measured value of leaf area for 74-112, 74-165, 75-225, 74-54, 74-1, 74-140, 74-158 and 74-148 Coffea arabica genotypes respectively. The model overestimated the areas of 74-112 and 74-1 with $0.17 \%$ and $0.035 \%$, respectively and underestimated the areas of $74-165,75-225$, $74-140,74-158,74-148$ and $74-54$ with $0.65 \%, 1.66 \%, 1.47 \%, 0.76 \%, 0.54 \%$ and $0.091 \%$, respectively. The bias of estimated area from the measured area is also very small which ranges between ( -0.44 to 0.06 ) (Figure 1 ) for all genotypes, showing the potential of estimating the leaf area. The findings of the present study were in agreement with many of the previous studies by Barros et al. (1973); cited in [7] for Coffea arabica (LA $=0.667 \mathrm{LW})$; [21] for Coffea canephora Pierre ex Froehner var. Conilon LA $=0.6587(\mathrm{LW})$ and $\mathrm{LA}=0.6533(\mathrm{LW})$; [22], for (Coffea arabica L.) of the Castillo LA $=\mathrm{LW}^{\star} 0.6612$ ). Many researchers also found similar results for other crops such as [29] for sweet cherry LA = 0.690LW; [30], for Capsicum annuum L. LA $=0.587(\mathrm{~L} \times \mathrm{W})$; [28] for grapevine $\mathrm{LA}=0.587(\mathrm{~L} \times \mathrm{W})$.

The same product of linear dimensions were also successfully used to estimate leaf area, with good accuracy and excellent precision, in different agronomic species, such as [27] Kumar and Sharma (2010 and 2013) (LA $=-3.44+$ $0.729 \mathrm{LW}$ ) for saffron (Salvia sclarea L.) and ( $\mathrm{Y}=0.333+0.603 \mathrm{LW}$ for Picrorhizakurroa, respectively, which depending on length multiplied by width (LW) as 

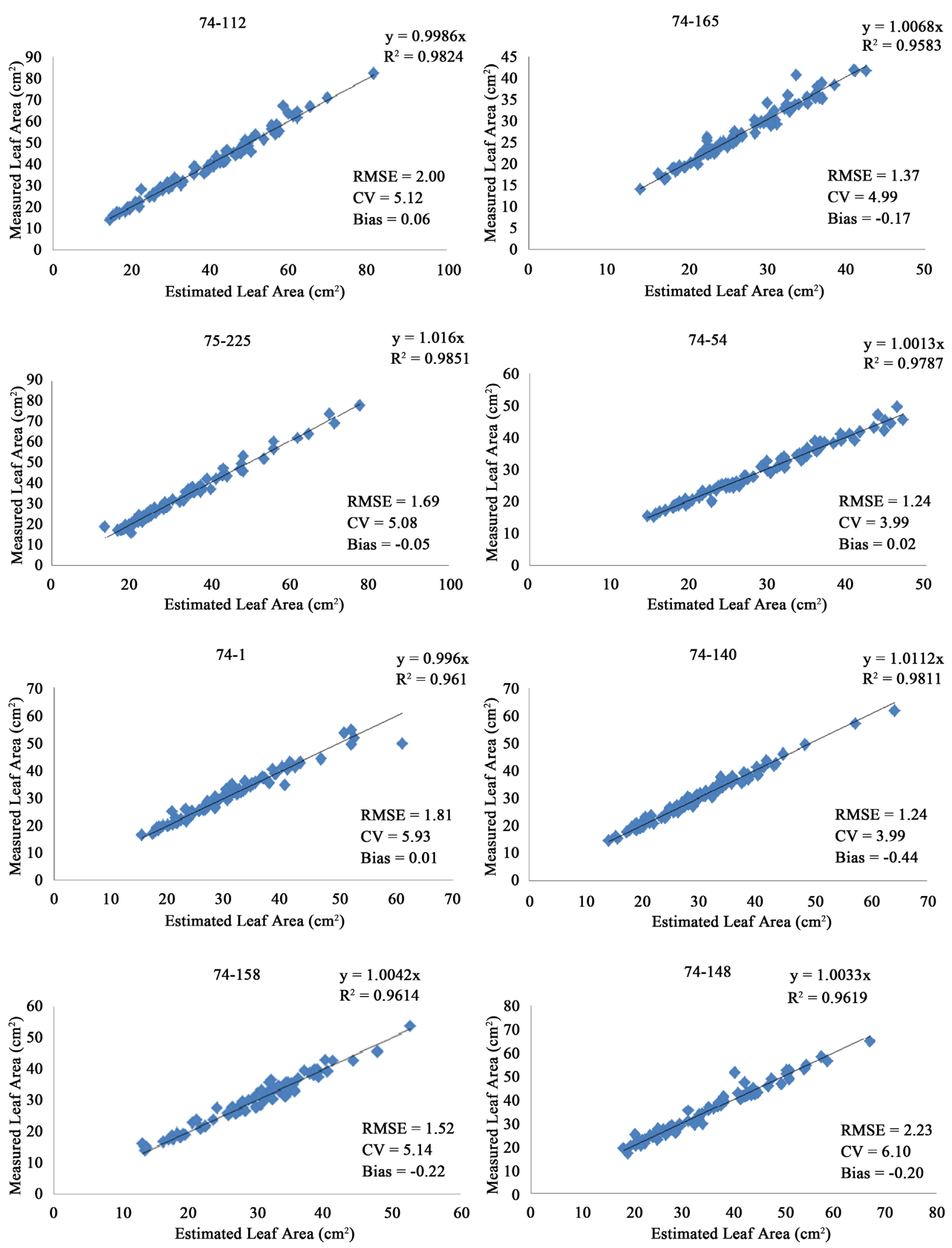

Figure 1. Plot of Estimated Leaf area (ELA) using best fitted model versus measured values of Leaf Areas (MLA) for eight Coffea arabica L. genotypes (See Tables 5-7). Dotted lines represent the 1:1 relationship between the predicted and measured values. 
independent variable gave more accurate estimation of leaf area compared to other models. Many other researchers also reported that leaf area can be estimated by linear measurement such as leaf width and leaf length in plants, such as [25] LA $=0.463+0.676 \mathrm{WL}$ Vernonia ferruginea; [12] $(\mathrm{LA}=0.03+0.71 \mathrm{LW}$ for raspberry, $\mathrm{LA}=1.72+0.69 \mathrm{LW}$ for redcurrant, $\mathrm{LA}=0.90+0.70 \mathrm{LW}$ for blackberry, LA $=0.58+0.72 \mathrm{LW}$ for gooseberry, and LA $=0.54+0.68 \mathrm{LW}$ for high bush blueberry, [27] hazelnut; [31] for faba bean (Viciafaba L.) and [32] for eggplant for developing simple and non-destructive models for estimating plant leaf area by using simple linear regression measurement. Also [33] found that the best fitting equations for estimating leaf area of oleander was (LA $=-22.562$ $+21.209 \mathrm{~W})$ and $(\mathrm{LA}=-22.226+2.978 \mathrm{~L})$ with $R^{2}=0.847$ and 0.893 respectively.

On the contrary power models was found by [7] LA $=0.6626(\mathrm{LW})^{1.0116}$ and [34], LA $=0.803(\mathrm{LW})^{0.985}$ for Coffea arabica $\mathrm{L}$ and Jatropha curcas $L$ respectively, which is not in agreement with this findings.

\section{Summary and Conclusions}

Allometric models to predict leaf area were calibrated and validated for eight Coffea arabica genotypes from the leaf width and leaf length. From the developed models, the simple linear regression models $(\mathrm{Y}=\mathrm{ax}+\mathrm{b})$ were more accurate than power $(\mathrm{Y}=\mathrm{ax})$ and logarithmic $(\mathrm{Y}=\mathrm{aln} \mathrm{x}+\mathrm{b})$ regression models for leaf area based on the model selection criteria (high $\mathrm{R}^{2}$ and low RMSE and low SE).

The finding revealed that the effects of growing altitude and genotype on the models were negligible for leaf area estimation. One common linear model $(\mathrm{Y}=$ $\left.0.6434 \mathrm{LW}, \mathrm{R}^{2}=0.9993, \mathrm{RMSE}=1.2387, \mathrm{SE}=0.0008\right)$ was developed for the eight genotypes of Coffea arabica grown at three different altitudes for leaf area estimation. This model gave accurate estimation of leaf area of the eight genotypes of Coffea arabica with an over or under estimation of less than $1.7 \%$. Therefore, this model can be proposed to be reliably used and with this developed model, researchers can estimate the leaf area of newly released eight genotypes of Coffea arabica at different altitudes accurately. Allometric model for leaf area estimation for the rest Coffea arabica genotypes should be investigated.

\section{Recommendations}

In this work, predictive models (the L-W product linear model without intercept) were developed to estimate the leaf area of eight Coffea arabica L. genotypes. Irrespective of genotype and growth altitude, this model can be used as an excellent and non-destructive tool for measuring leaf area of Coffea arabica L genotypes. This is very important especially when successive Leaf Area (LA) measurements are needed. Such models can simply and accurately estimate leaf area without the use of expensive instruments such as LA meter, digital camera, and scanner with image measurement software.

\section{Acknowledgements}

First, I would like to thank the almighty God who gave me patience to carry out 
this research and always with me in all my life and help me in all my ways. Next to God, I am profoundly indebted to my major advisor Dr. Adugna Debela and co-adviser Mr. Gerba Daba for their unreserved advice, guidance and valuable suggestions during my research work and thesis write-up. Without the encouragement, insight and professional expertise of my advisors, the completion of this work would have not been possible.

\section{References}

[1] Petit, N. (2007) Ethiopia's Coffee Sector: A Bitter or a Better Future. Journal of Agrarian Change, 7, 225-263. https://doi.org/10.1111/j.1471-0366.2007.00145.x

[2] Labouisse, J.P., Bellachew, B., Kotecha, S. and Bertrand, B. (2008) Current Status of Coffee (Coffea arabica L,) Genetic Resources in Ethiopia: Implication for Conservation. Genetic Resource and Crop Evolution, 55, 1079-1093.

https://doi.org/10.1007/s10722-008-9361-7

[3] Kurt, O., Uysal, H. and Uzun, S. (2005) Non-Destructive Leaf Area Estimation of Flax (Linun usitatissimum L.). Pakistan Journal of Botany, 37, 837.

[4] Pandey, S.K. and Singh, H. (2011) A Simple, Cost-Effective Method for Leaf Area Estimation. Journal of Botany, 2011, 1-6. https://doi.org/10.1155/2011/658240

[5] Zhang, L. and Pan, L. (2011) Allometric Models for Leaf Area Estimation across Different Leaf-Age Groups of Evergreen Broadleaved Trees in a Subtropical Forest. Photosynthetica, 49, 219-226. https://doi.org/10.1007/s11099-011-0027-X

[6] Wang, Z. and Zhang, L. (2012) Leaf Shape Alters the Coefficients of Leaf Area Estimation Models for Saussurea stoliczkai in Central Tibet. Photosynthetica, 50, 337-342. https://doi.org/10.1007/s11099-012-0039-1

[7] Antunes, W.C., Pompelli, M.F., Carretero, D.M. and DaMatta, F. (2008) Allometric Models for Non-Destructive Leaf Area Estimation in Coffee (Coffea arabica and Coffea canephora). Annals of Applied Biology, 153, 33-40. https://doi.org/10.1111/j.1744-7348.2008.00235.x

[8] Ghezehei, S., Annandale, J. and Everson, C. (2009) Shoot Allometry of Jatropha curcas. Southern Forests, 71, 279-286. https://doi.org/10.2989/SF.2009.71.4.5.1032

[9] Normand, F. and Lauri, P.-É. (2012) Assessing Allometric Models to Predict Vegetative Growth of Mango (Mangifera indica; Anacardiaceae) at the Current-Year Branch Scale. American Journal of Botany, 99, 425-437. https://doi.org/10.3732/ajb.1100249

[10] Fascella, G., Darwich, S. and Rouphael, Y. (2013) Validation of a Leaf Area Prediction Model Proposed for Rose. Chilean Journal of Agricultural Research, 73, 73-76. https://doi.org/10.4067/S0718-58392013000100011

[11] Lizaso, J.I., Batchelor, W.D. and Westgate, M.E. (2003) A Leaf Area Model to Simulate Cultivar-Specific Expansion and Senescence of Maize Leaves. Field Crops Research, 80, 1-17. https://doi.org/10.1016/S0378-4290(02)00151-X

[12] Fallovo, C., Cristofori, V., Mendoza-de Gyves, E., Rivera, C.M., Fanasca, S., Bignami, C., Sassine, Y. and Rouphael, Y. (2008) Leaf Area Estimation Model for Small Fruits from Linear Measurements. HortScience, 43, 2263-2267.

[13] Al-Barzinji, I.M. and Amin, B.M. (2016) Non-Destructive Method of Leaf Area Estimation for Oleander (Nerium oleander L.) Cultivated in the Iraqi Kurdistan Region. ARO-The Scientific Journal of Koya University, IV, Article ID: ARO.10088.

[14] Castelan-Estrada, M., Vivin, P. and Gaudilllère, J. (2002) Allometric Relationships 
to Estimate Seasonal Above-Ground Vegetative and Reproductive Biomass of Vitis vinifera L. Annals of Botany, 89, 401-408. https://doi.org/10.1093/aob/mcf059

[15] Daughtry, C.S.T. (1990) Direct Measurements of Canopy Structure. Remote Sensing Reviews, 5, 45-60. https://doi.org/10.1080/02757259009532121

[16] Nyakwende, E., Paull, C.J. and Atherton, J.G. (1997) Non-Destructive Determination of Leaf Area in Tomato Plants using Image Processing. Journal of Horticultural Science, 72, 225-262. https://doi.org/10.1080/14620316.1997.11515512

[17] Bignami, C. and Rossini, F. (1996) Image Analysis Estimation of Leaf Area Index and Plant Size of Young Hazelnut Plants. Journal of Horticultural Science, 71, 113-121. https://doi.org/10.1080/14620316.1996.11515387

[18] Parresol, B. (1999) Assessing Tree and Stand Biomass: A Review with Examples and Critical Comparisons. Journal of Forest Science, 45, 573-593.

[19] Beets, P.N., Kimberley, M.O., Oliver, G.R., Pearce, S.H., Graham, J.D. and Brandon, A. (2012) Allometric Equations for Estimating Carbon Stocks in Natural Forest in New Zealand. Forests, 3, 818-839. https://doi.org/10.3390/f3030818

[20] Brinate, S.V.B., Martins, L.D., Rodrigues, W.N., Colodetti, T.V., Amaral, J.F.T. and Tomaz, M.A. (2015) Accuracy of Linear Methods to Estimate the Leaf Area of Genotypes of Conilon Coffee. African Journal of Agricultural Research, 10, 2955-2960. https://doi.org/10.5897/AJAR2014.9336

[21] Muñoz, C.A.U., Arredondo, J.D.H., Restrepo, E.C.M., Rivera, R.D.M., Ruales, L.N.I., González, C.Y.C. and Ramos, C.P.F. (2015) Estimation of Leaf Area in Coffee Leaves (Coffea arabica L.) of the Castillo Variety. Bragantia, Campinas, 74, 412-416.

[22] Abrar, S., Negussie, M. and Meseret, D. (2013) Hybrid Coffee (Coffea arabica L.) Genotypes Quality Evaluation under Different Environment of Southern Ethiopia. Greener Journal of Agricultural Sciences, 4, 245-251. https://doi.org/10.15580/GJAS.2014.6.0523014244

[23] Kufa, T. (2012) Biomass Production and Distribution in Seedlings of Coffea arabica Genotypes under Contrasting Nursery Environments in Southwestern Ethiopia. Agricultural Sciences, 3, 835-843. https://doi.org/10.4236/as.2012.36101

[24] Walther, B.A. and Moore, J.L. (2005) The Concepts of Bias, Precision and Accuracy, and Their Use in Testing the Performance of Species Richness Estimators, with a Literature Review of Estimator Performance. Ecography, 28, 815-829. https://doi.org/10.1111/j.2005.0906-7590.04112.x

[25] Souza, M.C. and Amaral, C.L. (2013) Non-Destructive Linear Model for Leaf Area Estimation in Vernonia ferruginea less.

[26] Cristofori, V., Rouphael, Y., Mendoza-de Gyves, E. and Bigniami, C. (2007) A Simple Model for Estimating Leaf Area of Hazelnut from Linear Measurements. Scientia Horticulturae, 113, 221-225. https://doi.org/10.1016/j.scienta.2007.02.006

[27] Kumar, R. and Sharma, S. (2010) Allometric Model for Nondestructive Leaf Area Estimation in Clary Sage (Salvia sclarea L.). Photosynthetica, 48, 313-316.

[28] Tsialtas, J.T., Koundouras, S. and Zioziou, E. (2008) Leaf Area Estimation by Simple Measurements and Evaluation of Leaf Area Prediction Models in Cabernet-Sauvignon Grapevine Leaves. Photosynthetica, 46, 452-456. https://doi.org/10.1007/s11099-008-0077-x

[29] Cittadini, E.D. and Peri, L. (2006) Estimation of Leaf Area in Sweet Cherry using a Non-Destructive Method. La Revista de Investigaciones Agropecuarias, 35, 143-150.

[30] De Swart, E.A.M., Groenwold, R., Kanne, H.J., Stam, P., Marcelis, L.F.M. and Voorrips, R.E. (2004) Non-Destructive Estimation of Leaf Area for Different Plant Ages 
and Accessions of Capsicum annuum L. Journal of Horticultural Science \& Biotechnology, 79, 764-770. https://doi.org/10.1080/14620316.2004.11511840

[31] Peksen, E. (2007) Non-Destructive Leaf Area Estimation Model for Faba Bean ( Vicia faba L.). Scientia Horticulturae, 113, 322-328.

[32] Rivera, C.M., Rouphael, Y., Cardarelli, M. and Colla, G. (2007) A Simple and Accurate Equation for Estimating Individual Leaf Area of Eggplant from Linear Measurements. European Journal of Horticultural Science, 72, 228-230.

[33] Lakshmanan, C. and Pugazhendi, N. (2013) Leaf Area Prediction Models through Leaf Morphometry. A Multi-Disciplinary Refereed Journal, 6, 99-106.

[34] Pompelli, M.F., Antunes, W.C., Ferreira, D.T.R.G., Cavalcante, P.G.S., Wanderley-Filho, H.C.L. and Endres, L. (2011) Allometric Models for Non-Destructive Leaf Area Estimation of Jatropha curcas. Biomass and Bioenergy, 36, 77-85. 